\title{
RELATIONSHIP BETWEEN SPATIAL AND DEVELOPMENT PLANNING AT THE LOCAL LEVEL IN THE REPUBLIC OF SRPSKA, BOSNIA AND HERZEGOVINA
}

\author{
Branislav Bijelić ${ }^{* 1}$, Dejan P. Đorđević ${ }^{* *}$ \\ * Urbis centar Ltd, Banja Luka \\ ${ }^{*}$ University of Belgrade - Faculty of Geography, Belgrade
}

\begin{abstract}
The mutual relationship between spatial and development planning at the local level is a very current topic that has concrete consequences for development processes in local government units in the territory of Republika Srpska (RS). Although it is still unregulated from the legislative point of view, local development planning is much more present in practice, which is primarily manifested in the almost complete coverage of the territory of the RS by local development strategies. The connection of these documents to spatial and urban plans has not been treated in an appropriate way, which leads to a certain degree of their mutual inconsistency. The basic hypothesis of this paper arises from this statement, and that is that the lack of a clearly defined connection with spatial planning in the methodology of drafting local development documents leads to the inconsistency of these documents as the final result. As an auxiliary hypothesis, the assumption will be investigated that a large discrepancy in the coverage of the territory of the Republika Srpska between local development strategies and spatial plans of local government units also contributed to this inconsistency.
\end{abstract}

Key words: development, planning, local government unit, Republic of Srpska.

${ }^{1}$ Corresponding author: B. Bijelić, Urbis centar Ltd, Bulevar vojvode Stepe Stepanovića 101a, Banja Luka, Republic of Srpska, Bosnia and Herzegovina; email: bbijelic@urbiscentar.com 


\section{Introduction}

Most types of planning as activities of "designing the future" (Đorđević, 2004) are essentially focused on betterment the existing situation or development (Webber, 1983). While spatial planning primarily deals with the spatial dimension of development, modern development planning is aimed at achieving a higher level of development in its integral understanding that includes the economic, social and environmental aspects of development. It is a type of planning "in which various disciplines have met and collided, because in it (more than in other fields) there have been realised integrated forms of economic, social and even physical planning" (Archibugi, 2008). According to Dale (2005) it is "a normative pursuit explicitly aiming at improving aspects of the quality of life" and occurs "at various societal levels, from the local to the international". Some authors link development planning to "planning in and for less developed nations" and see it as "a way of promoting the economic and social advancement of these countries" (Alexander, 2000).

In the Republic of Srpska and Bosnia and Herzegovina (BiH), the predecessor of today's development planning in the past was social planning, which was the planning of economic and social development in the period $1945-1990$. According to Piha (1979), social planning was the most developed planning in the former Yugoslavia and one of the three subsystems of a unified planning system in addition to spatial planning and other planning (adjacent character plans). In practice, social planning was reduced to planning economic growth (Perišić, 1985). Changes in the socio-political system in the period 1990 - 1992 and war in the period 1992 - 1995 caused a kind of vacuum in the field of planning, which primarily affected to the disappearance of social planning. This once most developed type of planning was then collapsed (Vujošević, 2004) and at the beginning of the new millennium replaced by development planning, primarily at the local level.

However, the connection of local development documents of the new generation according to spatial and urban plans has not been treated in an appropriate way, which leads to a certain degree of their mutual inconsistency. The basic hypothesis of this paper arises from this statement, and that is that the lack of a clearly defined connection with spatial planning in the methodology of drafting local development documents leads to the inconsistency of these documents as the final result. As an auxiliary hypothesis, the assumption will be investigated that a large discrepancy in the coverage of the territory of the Republic of Srpska between local development strategies and spatial plans of local government units also contributed to this inconsistency, since the absence of these strategic spatial planning documents for a significant part of the territory of the Republic of Srpska practically prevents their use for the development of local development plans. 


\section{Materials and methods}

\section{The study area}

The research subject of this paper is the investigation of the relationship between spatial and development planning at the local level. The study area is the Republic of Srpska (RS), which represents an entity (federal-confederal unit) in Bosnia and Herzegovina. This entity covers mainly the northern and eastern part of Bosnia and Herzegovina. Its total area is $24,666 \mathrm{~km}^{2}$ or $48.17 \%$ of the total area of Bosnia and Herzegovina. It is located between $45^{\circ} 16^{\prime}$ and $42^{\circ} 33^{\prime}$ north longitude, and between $16^{\circ} 11^{\prime}$ and $19^{\circ} 37^{\prime}$ east latitude (Novi urbanistički zavod RS, 2015). There are 64 local government units (LGU) in the RS - 56 municipalities and 8 cities (N.B. the City of Istočno Sarajevo is a single local government unit comprising 6 municipalities). The RS has no regional level of government in its administrative division.

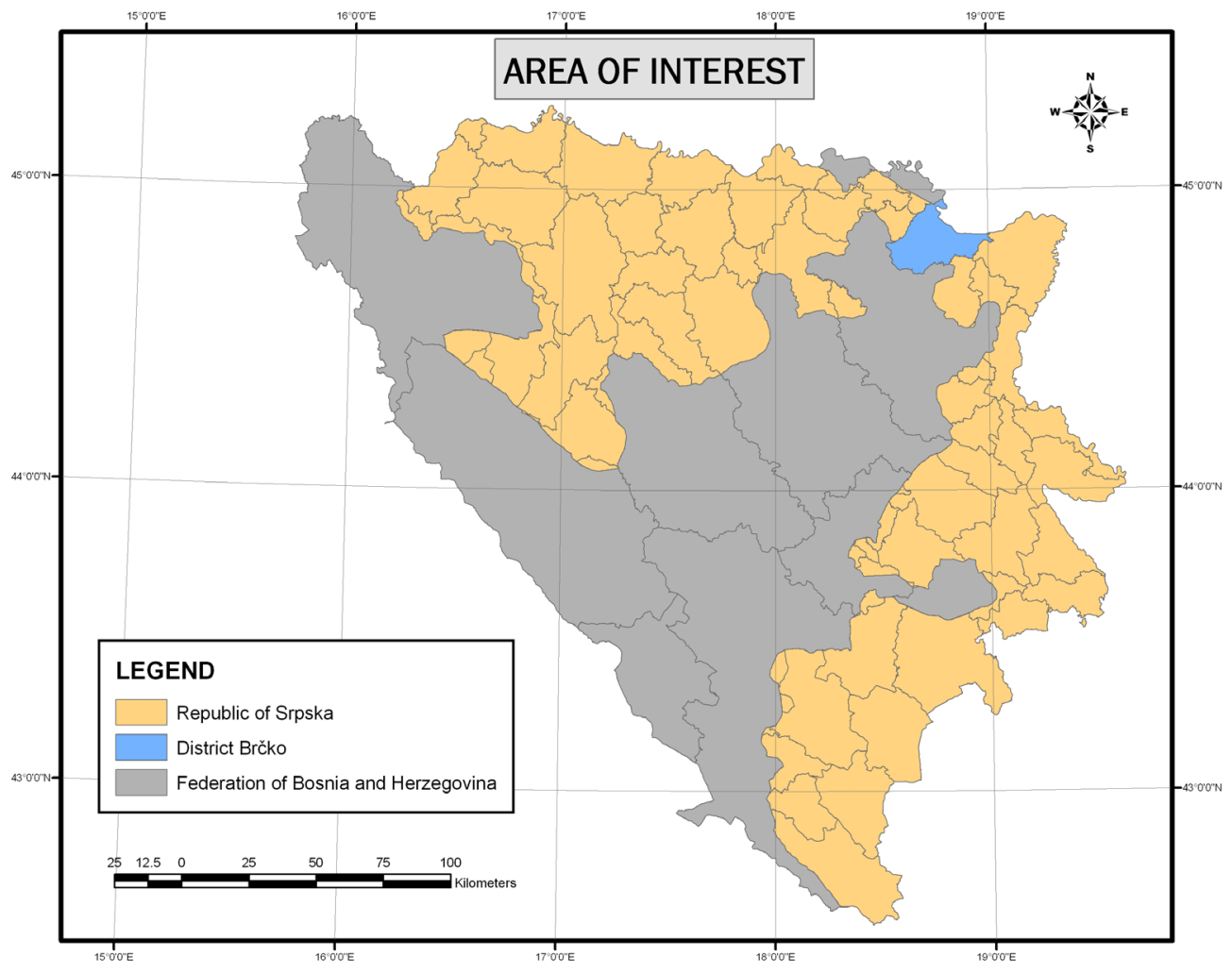

Figure 1. Position of the Republic of Srpska in Bosnia and Herzegovina

(Source: Authors) 


\section{Methodology}

The research in this paper is based on the analysis of two methodological frameworks used for the development of spatial plans of local government units and local development strategies. These are the Rulebook on the Method of Drafting, Content and Development of Spatial Planning Documents (Službeni glasnik RS, 2013), as well as publications - Policy Note on the Guiding Principles and a Standardised Approach to Local Development Planning in Bosnia and Herzegovina $(\mathrm{BiH})$, Integrated Local Development Planning Methodology - MiPRO (the first, theoretical part) and Methodology for Integrated Local Development Planning - MiPRO (the second, practical part). The first document is a bylaw issued by the Ministry of Spatial Planning, Construction and Ecology of the Republic of Srpska for the purpose of regulating the development of spatial planning documents in the RS, while the publications are implemented under the Integrated Local Development Project (ILDP) from 2011, which is a joint initiative the Swiss Agency for Development and Cooperation (SDC) and the United Nations Development Program in BiH (UNDP BiH), and represents an informal methodological framework for the development of local development strategies in the RS. It should be noted that in the other entity there is a bylaw that regulates the drafting of development documents - Regulation on the Development of Strategic Documents in the Federation of Bosnia and Herzegovina (Službene novine $\mathrm{FBiH}, 2019$ ). This regulation also treats the development of sectoral strategic documents in this entity.

In addition to this main research, an auxiliary research was conducted, which focused on a comparative analysis of the coverage of the territory of the Republic of Srpska by spatial plans of local government units and local development strategies.

\section{Results and discussion}

The analysis of the Rulebook on the Method of Drafting, Content and Development of Spatial Planning Documents from 2013, as a methodological framework for the development of all spatial planning documents, showed that the development strategies in Article 18 are listed by name as part of the information base within the technically preparation for the drafting the Spatial Plan of the Republic of Srpska. This article number is then mentioned in Article 88, which deals with technically preparation for the development of the spatial plan of the local government unit. Otherwise, the information base means a set of information from various relevant sources that is used for the purpose of drafting spatial planning documents. 
The publication "Policy Note on the Guiding Principles and a Standardised Approach to Local Development Planning in Bosnia and Herzegovina (BiH)" states that "guiding principles, characteristics and standardised approach to local development planning" should, among other things, create preconditions for "establishing a link between strategic and spatial planning". This link is shown graphically in the following figure.

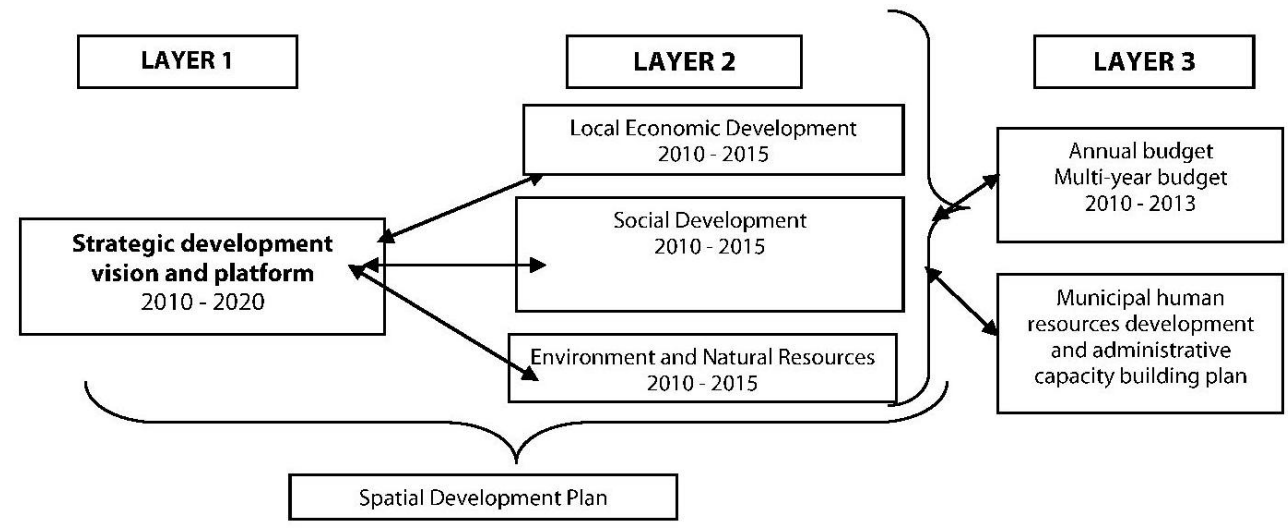

Figure 2. Local development planning matrix

(Source: Policy Note on the Guiding Principles and a Standardised Approach to Local Development Planning in Bosnia and Herzegovina (BiH))

The theoretical part of the Integrated Local Development Planning Methodology - MiPRO elaborates the guiding principles in a specific chapter "Linkages with spatial planning". This chapter points out that in methodological terms, "development strategies and sectoral development plans are complementary to and aligned with spatial plans in terms of time, content and methodology." It also states that "the key part of the strategic platform (vision and strategic development goals) should serve as a common landmark for both spatial and sectoral development plans". The penultimate paragraph of this chapter says that "in the implementation of sectoral development plans, it is important to follow the limitations set under spatial plans", and if these limitations are found to be an obstacle to the strategic interests of the community, "a regular procedure for amendments of the spatial plans should be initiated".

However, the practical part of the Methodology for Integrated Local Development Planning - MiPRO does not sufficiently elaborate the harmonization of local development strategies and spatial planning documents. In the chapter "Harmonization", in addition to the general theoretical review, concrete examples of the connection of spatial planning with sectoral development plans (economic development, social development and environmental protection) are given, but without stating a detailed methodological procedure of harmoniza- 
tion. The relationship between the spatial plan of the local government unit and the local development strategy is also dealt with in the chapter "Scenarios for application of the methodology", where two possible scenarios are considered - the existence of a current, updated spatial plan and its absence. In the first scenario, changes to the spatial plan "should be initiated only if solutions from the spatial plan present a significant limitation to strategic development interventions", while in the second scenario "strategic focuses, vision and strategic goals are then used when creating a spatial plan".

A comparative analysis of the coverage of the territory of Republika Srpska by spatial plans of local government units and local development strategies in October 2020 showed that the absence of an updated spatial plan of local government units is not a rare case in the RS, as shown in the following figure.

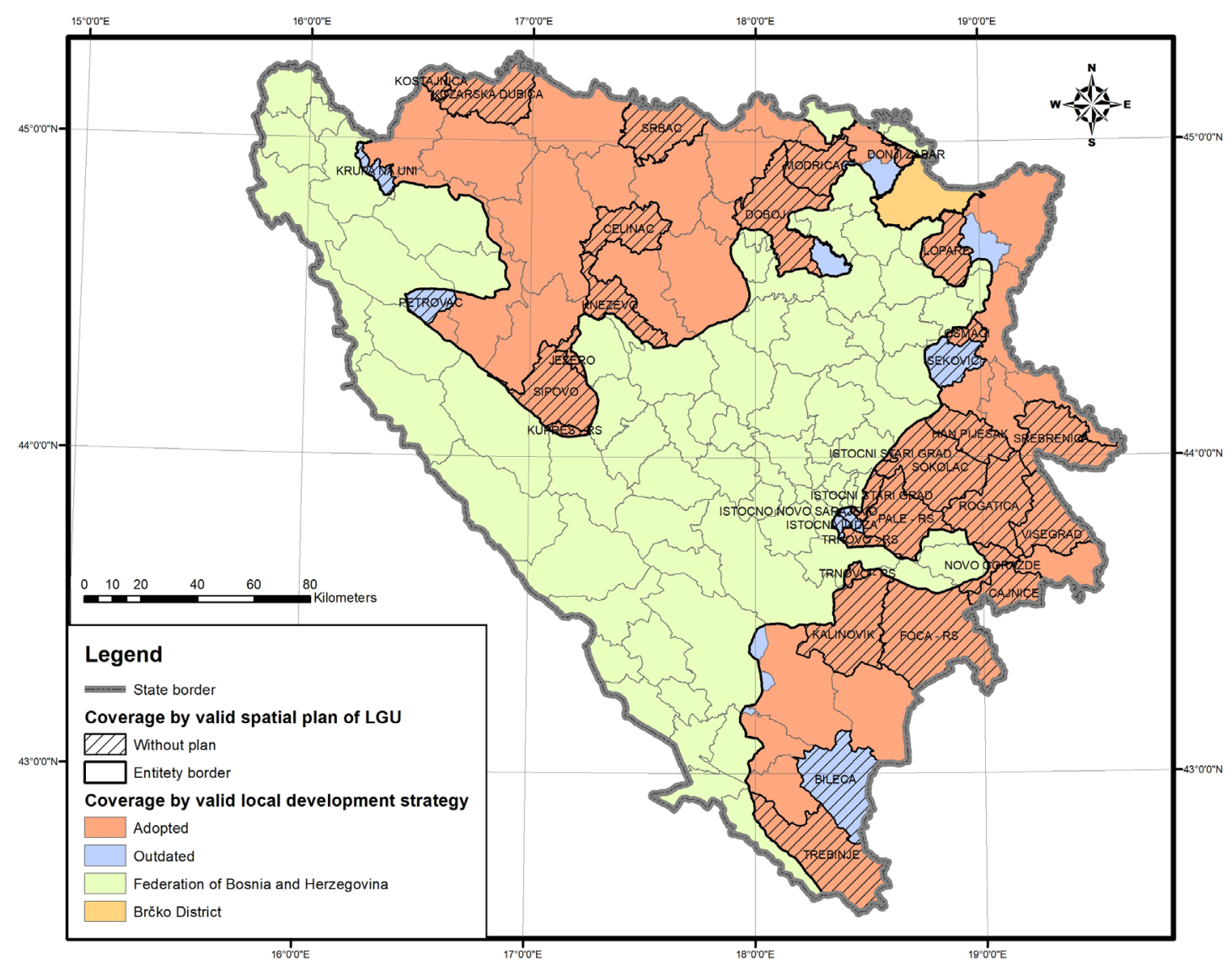

Figure 3. The coverage of the territory of Republika Srpska by spatial plans of local government units and local development strategies in October 2020

(Source: Authors) 
This picture shows that according to the situation from October 2020, as many as 31 local government units (2 cities and 29 municipalities) or $48.4 \%$ of their total number do not have a valid spatial plan, which is significantly worse than the coverage of the RS by local development strategies, because only 10 municipalities do not have an updated development strategy (15.6\%). Regarding local government units, which have adopted updated development strategies, the overwhelming majority $(90.7 \%)$ was developed according to the MiPRO methodology.

It should be emphasized that the practice (example of the Development Strategy of the Municipality of Gradiška for the period 2014 - 2020) has shown that even in the case of existence of an updated spatial plan of the local government unit there is a significant neglect of its planning propositions by the local development strategy, which takes on the role of a more dominant planning document, although due to a more comprehensive approach this function should in fact have a spatial plan.

\section{Conclusion}

The research of the relationship between spatial and development planning at the local level in the RS shows that in the methodology of drafting local development documents there is no clearly defined connection with spatial planning, ie the way of harmonization between spatial plans of local government units and local development strategies is not specified, but only a theoretical approach that considers scenarios for the existence of a current, updated spatial plan or its absence. Unfortunately, the MiPRO methodology does not treat the key issue of taking over planning propositions from valid and updated spatial plans and their conversion into programs, projects and measures of local development strategies, whereby it is necessary to take into account the better expert basis of propositions in spatial plans, and the different time horizons of these two types of planning documents. The role of spatial plans in this regard can not only be reduced to contributing to the development of socio-economic analysis in local development strategies through full or partial takeover of the analysis and evaluation of the existing situation of territory, but also needs to expand to provide inputs for sectoral plans through taking over and adjusting their planning propositions to the greatest extent possible.

However, the research has also shown that it is necessary to further specify the place of various updated integrated and sectoral development strategies, primarily local development strategies, in the methodology of drafting spatial planning documents (Rulebook on the Method of Drafting, Content and Development of Spatial Planning Documents), especially in the part related to 
the determination of planning propositions through the critical takeover of programs, projects and measures with a pronounced spatial dimension from these documents.

Finally, a comparative analysis of the coverage of the RS territory by spatial plans of local government units and local development strategies in October 2020 confirmed the auxiliary hypothesis that the large discrepancy in the coverage of the RS territory between local development strategies and spatial plans of local government units also contributed to the inconsistency between spatial and development planning at the local level. As many as 31 local self-government units or $48.4 \%$ of their total number do not have a valid spatial plan, which is significantly worse than the coverage of the RS territory with local development strategies, since only 10 municipalities do not have an updated development strategy (15.6\%). Unfortunately, the existence of an updated spatial plan of a local government unit does not guarantee that most of its planning propositions will find their place in the local development strategy, which is why the spatial plan should be the primary source for creating programs, projects and measures within sectoral plans of local development strategies.

By development of the missing spatial plans for 31 local government units ( 2 cities and 29 municipalities) in the RS, with updating development strategies for 10 municipalities in the next few years, and generally taking into account the documents that expire in the meantime, a solid basis would be created, which would enable that the inconsistency between spatial and development planning at the local level to be greatly reduced.

\section{References}

Alexander, R.E. (2000). Approaches to planning: Introducing Current Planning Theories, Concepts and Issues (Second Edition). Philadelphia: Gordon and Breach Science Publishers.

Archibugi, F. (2008). Planning Theory: From the Political Debate to the Methodological Reconstruction. Springer.

Bublin, M. (2000). Prostorno planiranje. Sarajevo: Univerzitetska knjiga.

Dale, R. (2005). Development Planning: Concepts and Tools for Planners, Managers and Facilitators. London: Zed Books.

Đorđević, D. (2004). Uvod u teoriju planiranja. Beograd: Univerzitet u Beogradu Geografski fakultet.

Đorđević, D., \& Dabović, T. (2009). Osnove prostornog planiranja. Beograd: Univerzitet u Beogradu - Geografski fakultet.

Novi urbanistički zavod RS. (2015). Izmjene i dopune Prostornog plana Republike Srpske 
do 2025.godine. Banja Luka: Novi urbanistički zavod RS.

Opština Gradiška. (2014). Strategije razvoja opštine Gradiška za period 2014 - 2020. godina. Gradiška: Opština Gradiška.

Perišić, D. (1985). O prostornom planiranju. Beograd: Institut za arhitekturu, urbanizam i prostorno planiranje Srbije.

Petrić, J. i Milinković, M. (2017). Pojmovnik prostornog planiranja. Beograd: Institut za arhitekturu, urbanizam i prostorno planiranje Srbije.

Piha, B. (1979). Osnove prostornog planiranja. Beograd: Univerzitet u Beogradu.

Službene novine Federacije Bosne i Hercegovine. (2019). Uredba o izradi strateških dokumenata u Federaciji Bosne i Hercegovine ("Službene novine FBiH", br. 74/19). Sarajevo: Službene novine Federacije Bosne i Hercegovine.

Službeni glasnik Republike Srpske. (2013). Pravilnik o načinu izrade, sadržaju i formiranju dokumenata prostornog uređenja (“Službeni glasnik RS”, br. 69/13). Banja Luka: Službeni glasnik Republike Srpske.

UNDP BiH. (2011). Integrated Local Development Planning Methodology - MiPRO (the first, theoretical part). Sarajevo: UNDP BiH.

UNDP BiH. (2011). Methodology for Integrated Local Development Planning - MiPRO (the second, practical part). Sarajevo: UNDP BiH.

UNDP BiH. (2011). Policy Note on the Guiding Principles and a Standardised Approach to Local Development Planning in Bosnia and Herzegovina (BiH). Sarajevo: UNDP BiH.

Urbanistički zavod RS. (2007). Prostorni plan opštine Gradiška 2005 - 2020. Banja Luka: Urbanistički zavod RS a.d.

Vujošević, M. (2004). The search for a new development planning/policy mode: Problems of expertise in the transition period. Spatium, 10, pp. 12-18.

Webber, M. M. (1983). The myth of rationality: development planning reconsidered. Environment and Planning B: Urban Analytics and City Science, 10 (1), pp. 89-99. 
